\title{
Nutritive value of three organisms from mangrove ecosystem: Ucides cordatus (Linnaeus, 1763), Mytella sp. (Soot-Ryen, 1955) and Crassostrea rhizophorae (Guilding, 1828)
}

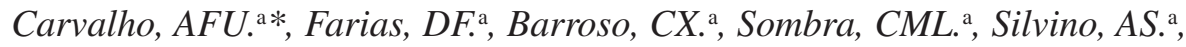 \\ Menezes, MOT. ${ }^{\mathrm{a}}$, Soares, MO. ${ }^{\mathrm{a}}$, Fernandes, DAO. $^{\mathrm{a}}$ and Gouveia, ST. ${ }^{\mathrm{b}}$ \\ aDepartamento de Biologia, Universidade Federal do Ceará - UFC \\ Av. Mister Hull, s/n, Campus do Pici, CEP 60455-970, Fortaleza, Ceará, Brazil \\ 'Departamento de Química Analítica, Universidade Federal do Ceará - UFC, \\ Av. Mister Hull, s/n, Campus do Pici, CEP 60455-970, Fortaleza, CE, Brazil \\ *e-mail: aurano@ufc.br \\ Received November 28, 2006 - Accepted June 29, 2007 - Distributed November 30, 2007
}

Mangrove ecosystems have always provided abundant food to man, constituting an important source of income for mangrove populations. In fact, a great part of protein consumed comes from the mangrove ecosystem where these populations practice self-subsistence extractivism (Schaeffer-Novelli, 2003).

Analytic studies of nutrients in Brazilian food were basically carried out from the 1940s and 1950s to early 1960s. Recently, however, due to the rise of new scientific concepts in nutrition and food science, the interest has been renewed (Lajolo, 1995 apud. Torres et al., 2000). Thus, the objective of this work is to assess the nutritional value of three mangrove animals: the crab Ucides cordatus, the oyster Crassostrea rhizophorae, and the mussel Mytella sp., by analysis of proximate composition, mineral content and caloric values of their edible parts.

Frozen mussel edible parts $(0.5 \mathrm{~kg})$ were bought at a local seafood store. Two samples of oysters $(0.5 \mathrm{~kg})$ were used: a frozen shelless sample for proximate composition analysis and a fresh one for moisture determination. Both mussels and oysters were collected in Parnaíba delta (Piauí, Brazil). Crab samples $(0.4 \mathrm{~kg})$ were constituted of claw meat and were obtained in Camocim (Ceará, Brazil) and brought frozen to the laboratory. Samples of all animals were defrosted and then dehydrated in an oven at $100{ }^{\circ} \mathrm{C}$ until constant weight. Dry samples were ground and subsequently used for total protein, lipids and ash determination (A.O.A.C., 1990). Carbohydrate content was calculated by difference and total caloric value by the Atwater system (Morowitz, 1968). Nine minerals were determined by atomic emission spectroscopy (ICP-OES) after appropriate pre-treatment of samples (Gouveia et al., 2002). The data were analyzed using a non-parametric test of multiple comparison of protein means (Kruskal-Wallis) and Dunn test for paired analysis of the protein content mean. Fisher's and Qui-Square $\left(\chi^{2}\right)$ test were used to analyze proportions.

The results (Table 1) showed that the animals have high moisture content, ranging from 74.75 to $92.17 \%$, the oyster showing the highest value since the samples were fresh, with no loss of perivisceral water. Protein content in dry weight basis varied between 41.14 to $78.50 \%$. The crab showed higher protein content when compared to the mussel and the oyster ( 78.50 vs. 63.75 and $40.14 \%$, respectively). Nevertheless, in wet weight basis, the crabs' protein content was lower than that of the mussels. Due to the small sample size, it was not possible to make any statistical inference in the lipid, ashes and carbohydrate contents. The oysters showed the highest lipid content in dry weight basis $(13.51 \%)$. As to wet weight basis, the lipid contents were quite low ranging from 0.25 to $1.19 \%$. The ash content on wet basis varied from 0.50 to $3.37 \%$. Carbohydrate content ranged from 2.26 (crab) to $4.60 \%$ (mussel). These shellfishes represent a good source of minerals (Table 2), satisfying from 7.6 to $100 \%$ the highest requirements suggested by The Food and Nutrition Board,

Table 1. Proximate Composition and caloric value of three animals from the mangrove: the crab Ucides cordatus, the oyster Crassostrea rhizophorae, and the mussel Mytella sp.

\begin{tabular}{|c|c|c|c|c|c|c|}
\hline \multicolumn{7}{|c|}{ Proximate composition (\%) } \\
\hline \multirow[t]{2}{*}{ Shellfish } & \multicolumn{5}{|c|}{ Wet basis } & \multirow{2}{*}{$\begin{array}{c}\text { Energy } \\
\left(\text { kcal.g }^{-1}\right)\end{array}$} \\
\hline & Moisture & Protein* & Lipids & Ash & Carbohydrate $* *$ & \\
\hline Crab & $82.97 \pm 6.03$ & $13.37 \pm 0.24$ & $0.25 \pm 0.00$ & $1.15 \pm 0.04$ & 2.26 & 0.69 \\
\hline Oyster & $92.17 \pm 5.42$ & $3.22 \pm 0.09$ & $1.06 \pm 0.00$ & $0.50 \pm 0.02$ & 3.05 & 0.36 \\
\hline Mussel & $74.75 \pm 6.69$ & $16.09 \pm 0.69$ & $1.19 \pm 0.03$ & $3.37 \pm 0.12$ & 4.60 & 0.99 \\
\hline \multicolumn{7}{|c|}{ Dry basis } \\
\hline Crab & - & $78.50 \pm 1.42$ & $1.48 \pm 0.02$ & $6.77 \pm 0.24$ & 13.25 & 4.07 \\
\hline Oyster & - & $41.14 \pm 1.15$ & $13.51 \pm 0.02$ & $6.43 \pm 0.20$ & 38.92 & 3.55 \\
\hline Mussel & - & $63.75 \pm 2.72$ & $4.70 \pm 0.11$ & $13.34 \pm 0.48$ & 18.22 & 3.95 \\
\hline
\end{tabular}

Values are means \pm standard deviation, $\mathrm{n}=3 . * \mathrm{~N}$ total $\times 6.25 . * *$ Calculated by difference. 
Table 2. Mineral content of three animals from the mangrove: the crab Ucides cordatus, the oyster Crassostrea rhizophorae, and the mussel Mytella sp.

\begin{tabular}{|c|c|c|c|c|c|c|}
\hline \multirow[t]{2}{*}{ Minerals } & \multicolumn{2}{|c|}{ Crab } & \multicolumn{2}{|c|}{ Oyster } & \multicolumn{2}{|c|}{ Mussel } \\
\hline & mg.100 g $\mathrm{g}^{-1 *}$ & $\mathbf{R D A}^{* *}(\%)$ & mg.100 $\mathrm{g}^{-1}$ & $\%$ RDA (\%) & mg.100 g-1 & RDA (\%) \\
\hline Calcium (Ca) & $180.57 \pm 50.60$ & 13.89 & $167.78 \pm 9.42$ & 12.91 & $268.37 \pm 12.11$ & 20.64 \\
\hline Phosphorus (P) & $5104.73 \pm 291.87$ & $>100$ & $5157.26 \pm 128.64$ & $>100$ & $4824.84 \pm 150.63$ & $>100$ \\
\hline Magnesium (Mg) & $123.37 \pm 16.90$ & 29.37 & $157.83 \pm 9.40$ & 37.58 & $159.07 \pm 5.36$ & 37.87 \\
\hline Iron $(\mathrm{Fe})$ & $5.32 \pm 0.02$ & 19.70 & $30.57 \pm 7.28$ & $>100$ & $152.40 \pm 1.03$ & $>100$ \\
\hline Zinc (Zn) & $34.67 \pm 1.55$ & $>100$ & $151.61 \pm 0.55$ & $>100$ & $5.01 \pm 4.24$ & 38.54 \\
\hline Manganese (Mn) & $0.38 \pm 0.03$ & 14.61 & $0.96 \pm 0.34$ & 36.92 & $9.04 \pm 0.02$ & $>100$ \\
\hline Sodium (Na) & $1410.37 \pm 19.78$ & 94.02 & $2270.02 \pm 79.80$ & $>100$ & $4609.59 \pm 69.46$ & $>100$ \\
\hline Copper $(\mathrm{Cu})$ & $6.78 \pm 0.08$ & $>100$ & $6.55 \pm 0.05$ & $>100$ & $1.28 \pm 0.15$ & $>100$ \\
\hline Potassium $(\mathrm{K})$ & $706.83 \pm 12.39$ & 13.86 & $948.19 \pm 18.64$ & 18.59 & $523.47 \pm 32.22$ & 10.26 \\
\hline
\end{tabular}

* mg of mineral in $100 \mathrm{~g}$ of dry shellfish; ** mineral percentage in relation to the highest requirements of the Recommended Dietary Allowances - RDA (Food and Nutrition Board, IOM, 2004).

Institute of Medicine (2002). This can be due to the feeding behavior and holding capacity of minerals shown by these organisms. Pedrosa and Cozzolino (2001), using processed samples, have reported $79.71 \%$ moisture for oysters and $84.42 \%$ for crabs. The difference between data of both studies was higher for oysters $(12.46 \%)$ than for crabs $(1.45 \%)$, probably due to the fact that the present study used fresh oysters and processed crabs. Although the moisture values of both studies do not differ significantly, the results in dry weight was 3 times smaller than those of Pedrosa and Cozzolino (2001). The crab, the oyster and the mussel meet 20,5 and $25 \%$, respectively, of the minimum requirements of the daily protein value necessary for breastfeeding women, the most demanding condition for protein needs, according to the The Food and Nutrition Board, Institute of Medicine (2002). The protein content of crabs does not differ in both studies. However, the protein content for the oyster was 5 times greater than that of the present study. This may be related to the different ways the samples were processed in the two studies. The low lipid content in the crab $(0.25 \%)$ is probably due to the fact that the sample was basically constituted by muscular tissue from claws. Pedrosa and Cozzolino (2001) have reported $0.49 \%$ of lipid for the crab and $1.79 \%$ for the oyster, which do not differ much from the present data. As to ash and carbohydrate values, those for crab and oyster did not show any significant difference between both studies. The mussel and the oyster showed the highest carbohydrate contents when compared to lipids, in a $3: 1$ proportion. This agrees with the fact that animals facing unfavorable conditions for long periods, e.g. anoxia by closing the valves, preferably use carbohydrates as energy reserve (SchmidtNielsen, 2002). The results of proximate composition for oyster and crab were consistent with data found in the specialized literature. The only exception was the oyster protein content which can be explained by the difference in moisture content. No work has been found on the proximate composition of the mussel Mytella sp. The availability of these and other animals as food for these communities depends, however, on the state of mangrove conservation and level of water contamination. If the mangrove is in a highly advanced level of degradation, it may not present favorable conditions for species survival and if the water is polluted, man's consumption of these organisms may not be safe since oysters and mussels are filter-feeding animals and can accumulate harmful substances. In conclusion, these animals are of great importance for nutrition of poor mangrove communities due to their high protein and mineral contents. The mangrove ecosystem conservation is of primary importance for the sustainability of fishing resources besides maintaining a dynamic balance on the coastal zone and preserving biodiversity.

\section{References}

A.O.A.C. (ASSOCIATION OF OFFICIAL AGRICULTURAL CHEMISTS), 1990. Official Methods of the Association of the Agricultural Chemists. Arlington, Virginia, 15 ${ }^{\text {th }}, 1115 \mathrm{p}$.

FOOD AND NUTRITION BOARD, INSTITUTE OF MEDICINE, NATIONAL ACADEMIES, 2002. Dietary Reference Intakes for Energy, carbohydrates, fiber, fat, fatty acids, cholesterol, protein and amino acids. Available at http:// nap.edu [june 2007].

-, 2004. Dietary Reference Intakes (DRIs): Recommended Intakes for Individuals, Elements. Available at http://nap.edu, [june 2007].

GOUVEIA ST., LOPES GS., FATIBELLO-FILHO O, LOPES, GS. and NOGUEIRA, ARA., 2002. Homogenization of breakfast cereals using cryogenic grinding. J Food Eng., vol. 51, no. 1, p. 59-63.

MOROWITZ, HJ., 1968. The Atwater System of calculating caloric values of diets. J. Nutr., vol. 28, p. 443-452.

PEDROSA, LFC. and COZZOLINO, SMF., 2001. Composição centesimal e de minerais de mariscos crus e cozidos da cidade de Natal/RN. Ciênc. Tecnol. Aliment., vol. 21 , no. 2 , p. 154-157.

SCHAEFFER-NOVELLI, Y., 2003. O papel ecológico e sócioeconômico dos manguezais, p. 46-47. In CAMPOS, AA. (ed.), A zona costeira do Ceará - diagnóstico para a gestão integrada. Aquasis, Fortaleza.

SCHMIDT-NIELSEN, K., 2002. Fisiologia animal: adaptação e meio ambiente. Santos Editora, São Paulo, $5^{\mathrm{a}}$ ed, 611p.

TORRES,EAFS.,CAMPOS,NC.,DUARTE,M.,GARBELOTTI, ML., PHILIPPI, ST., RODRIGUES, RSM., 2000. Composição centesimal e valor calórico de alimentos de origem animal. Ciênc. Tecnol. Aliment., vol. 20, no. 2, p. 45-150. 